\title{
Gregorio Vásquez de Arce y Ceballos (1638-1711) in Viceregal Colombia: Workshop Practices and the Role of Draftsmanship
}

\author{
Michael A. Brown
}

Volume 38, numéro 2, 2013

Contemporary Scholarship on Latin American Art

Approches contemporaines de l'art latino-américain

URI : https://id.erudit.org/iderudit/1020794ar

DOI : https://doi.org/10.7202/1020794ar

Aller au sommaire du numéro

Éditeur(s)

UAAC-AAUC (University Art Association of Canada | Association d'art des universités du Canada)

ISSN

0315-9906 (imprimé)

1981-4778 (numérique)

Découvrir la revue

Citer cet article

Brown, M. A. (2013). Gregorio Vásquez de Arce y Ceballos (1638-1711) in Viceregal Colombia: Workshop Practices and the Role of Draftsmanship. RACAR : Revue d'art canadienne / Canadian Art Review, 38(2), 56-70.

https://doi.org/10.7202/1020794ar

\section{Résumé de l'article}

Le peintre colombien Gregorio Vásquez de Arce y Ceballos (1638-1711) est né d'une famille originaire de Séville et installée à Bogotá depuis la fin du XVI ${ }^{\mathrm{e}}$ siècle. À l'époque de Vásquez, Bogotá était l'un des centres artistiques les plus importants du vice-royaume espagnol de la Nouvelle-Grenade, qui couvrait les actuels pays de l'Équateur et de la Colombie, vers le nord, en direction du Panama et du Venezuela. Vásquez est un personnage important dans l'histoire de l'art des colonies espagnoles, notamment dû au grand nombre de dessins qu'il a laissés, dont au moins 106 survivent. Reconnu surtout pour ses travaux pour différentes institutions religieuses à Bogotá, Tunja et ailleurs dans la Nouvelle-Grenade, il est l'un des peintres les plus prolifiques des trois siècles d'histoire des colonies américaines espagnoles. La commande la plus importante de Vásquez est probablement celle de la douzaine de peintures qui décorent la chapelle du Sagrario, construite entre 1660 et 1700 et adjacente à la cathédrale de Bogotá. L'énorme production artistique de Vásquez a été possible grâce à un atelier qui semble avoir inclus son frère, sa fille et son fils. Un petit groupe de peintures, récemment découvert au Denver Art Museum, est ici attribué à Gregorio Vásquez et à son atelier. L'étude de ces tableaux suscite une nouvelle réflexion sur les pratiques d'atelier et les méthodes d'enseignement de ce grand peintre, incluant le rôle primordial des gravures européennes et des dessins du maître.
Tous droits réservés @ C UAAC-AAUC (University Art Association of Canada | Association d'art des universités du Canada), 2013
Ce document est protégé par la loi sur le droit d'auteur. L'utilisation des services d'Érudit (y compris la reproduction) est assujettie à sa politique d'utilisation que vous pouvez consulter en ligne.

https://apropos.erudit.org/fr/usagers/politique-dutilisation/ 


\title{
Gregorio Vásquez de Arce y Ceballos (1638-171I) in Viceregal Colombia: Workshop Practices and the Role of Draftsmanship
}

\author{
Michael A. Brown, Denver Art Museum
}

\section{Résumé}

Le peintre colombien Gregorio Vásquez de Arce y Ceballos (1638-171 I) est né d'une famille originaire de Séville et installée à Bogotá depuis la fin du XVle siècle. À l'époque de Vásquez, Bogotá était l'un des centres artistiques les plus importants du vice-royaume espagnol de la NouvelleGrenade, qui couvrait les actuels pays de l'Équateur et de la Colombie, vers le nord, en direction du Panama et du Venezuela. Vásquez est un personnage important dans l'histoire de l'art des colonies espagnoles, notamment dû au grand nombre de dessins qu'il a laissés, dont au moins 106 survivent. Reconnu surtout pour ses travaux pour différentes institutions religieuses à Bogotá, Tunja et ailleurs dans la Nouvelle-Grenade, il est l'un des peintres les plus prolifiques des trois siècles d'histoire des colonies américaines espagnoles. La commande la plus importante de Vásquez est probablement celle de la douzaine de peintures qui décorent la chapelle du Sagrario, construite entre 1660 et 1700 et adjacente à la cathédrale de Bogotá. L'énorme production artistique de Vásquez a été possible grâce à un atelier qui semble avoir inclus son frère, sa fille et son fils. Un petit groupe de peintures, récemment découvert au Denver Art Museum, est ici attribué à Gregorio Vásquez et à son atelier. L'étude de ces tableaux suscite une nouvelle réflexion sur les pratiques d'atelier et les méthodes d'enseignement de ce grand peintre, incluant le rôle primordial des gravures européennes et des dessins du maître.

Introduction

$S_{\text {itita }}$ high in the northern Andes, Santa Fe de Bogotá had begun to emerge as an important artistic centre by the time its most famous colonial-era painter, Gregorio Vásquez de Arce y Ceballos, was born on 9 May 1638. Vásquez's family had come from Seville at the end of the sixteenth century, perhaps attracted by the opportunities offered by Bogotás commercial position as the hub of the Spanish viceroyalty of New Granada, a vast area of South America that included much of present-day Ecuador, Colombia, Panama, and Venezuela. ${ }^{1}$ By 1680, Gregorio Vásquez had become Bogotás most prominent and prolific artist; with the help of a workshop that included his brother, daughter, and son, he produced more than 500 paintings and drawings during his fortyyear career. Vásquez is an important figure in the history of Spanish viceregal art, perhaps most notably due to his extensive corpus of drawings, of which at least 106 sheets survive. Best known for the work he did for various religious institutions in Bogotá, Tunja, and elsewhere in New Granada, Vásquez’s most important commission was for the decoration of the new Sagrario Chapel, which was constructed between 1660 and 1700, adjacent to the cathedral in Bogotá. The commission comprised dozens of paintings and occupied Vásquez and his workshop for several decades.

Exceptionally few drawings by other artists have surfaced from the viceregal period in Latin America, leaving the impression-perhaps inaccurate- that draftsmanship was rarely practised there, if at all. Vásquez's body of work confirms that drawing was certainly an integral part of his artistic production, and a consideration of his studio practices suggests that it was also part of his own apprenticeship in Bogotá. The current study explores the working methods of Gregorio Vásquez, in particular the important and perhaps atypical role that draftsmanship played in his creative process. Vásquez's workshop brings to mind those of Dutch artists like Rembrandt and his followers in its ability to exploit a growing art market, and the drawing academy of Bartolomé Esteban Murillo (1617-82) in its emphasis on draftsmanship, though with less demonstrable attention on life drawing. Close scholarly considerations of seventeenth-century artists' workshop practices have proven especially enlightening in the case of Rubens, Rembrandt, and Poussin, among others. In particular, the production of multiples and variants by established studio assistants is common to these painters, including Gregorio Vásquez.

A consideration of four previously unidentified paintings in the collection of the Denver Art Museum, here attributed to Vásquez and his workshop for the first time, suggests that artistic production and pedagogy were inextricably linked in his studio practice. All four are variants of known Vásquez compositions. The paintings are The Temptation of Saint Thomas Aquinas, The Death of Saint Dominic, The Virgin Mary in Prayer, and The Penitent Mary Magdalene, all dating from the last quarter of the seventeenth century. Daniel Casey Stapleton (1855-1920), an Anglo-American businessman and adventurer, acquired the panels in the early twentieth century, along with several hundred other Spanish colonial objects, including furniture, silver, and sculptures, which he shipped to his wife's Omaha, Nebraska, residence before 1914. Stapleton's heirs gifted the collection to the Denver Art Museum in $1990 .{ }^{2}$ An examination of this small group of paintings, within the context of Spanish viceregal painting in general, provides new insight into this great painter's studio practices and teaching methods, including the prominent role played by European prints and the master's own drawings. 
Gregorio Vásquez and Painting in Early Modern Latin America

Long a household name in Colombia, Gregorio Vásquez de Arce y Ceballos is today a relatively obscure figure to most of the world despite the inclusion of his work in several important pan-Latin American art exhibitions in Europe and the United States. Debates about quality aside, Vásquez's works certainly merit such representation on the global stage; by any objective measure, he was a successful and sought-after painter with a lasting impact on generations of artists in Colombia. However, his critical fortunes have largely been confined to and defined within Colombia's borders. As Clara Bargellini has pointed out, he was the first artist in colonial Latin America to feature in a monographic study and catalogue raisonné, more than three decades before comparable treatments of Melchor Pérez Holguín (c. 1665-after 1732) or Cristóbal de Villalpando (c. 1649-1714) were to appear. ${ }^{3}$ Mexico and Peru have enjoyed the lion's share of international scholarly attention to the history of viceregal Latin American art. For much of the twentieth century, the historiography of Latin American art was dominated by scholars within each country of origin, resulting in many separate narratives. ${ }^{4}$ Forming a unified narrative of the development of colonial Latin America's artistic production has proved impractical if not entirely impossible; but here a few common threads provide some context for Gregorio Vásquez and his work.

In the century following the Spanish conquest, the viceroyalties witnessed a significant influx of artists from Italy, the Southern Netherlands, and Spain, who were charged with training an Indigenous workforce in European techniques and the visual language of Roman Catholicism. Many of the earliest immigrant artist-educators travelled with Franciscan and Augustinian missionaries or were friars themselves, and many brought engravings and illustrated emblem books from Europe as pedagogical aides. By the mid-sixteenth century, a second wave of immigration began, which included such influential figures in New Spain as Simón Pereyns (d. 1589) from Antwerp and Andrés de la Concha (1568-1612) from Seville, who arrived in 1566 and 1568 respectively. The Italian painters Bernardo Bitti (1548-1610), a mostly itinerant Jesuit, and Mateo Pérez de Alesio (1547-c. 1616), whose work survives in the Sistine Chapel and in the cathedral of Seville, were active in Peru in the final quarter of the sixteenth century. Another Italian, Angelino Medoro (1567-c. 1631), worked for several years in Tunja and Bogotá before relocating to Lima. Pérez de Alesio and Medoro, especially, left a lasting artistic impact on South America, not only through paintings but also through students and followers, resulting in an Italianate artistic foundation that stretched from Lima throughout the Andean world, including Bogotá and Quito. 5 In 1588, Medoro married the daughter of a prominent Spanish official in Colombia and settled for several years in Bogotá. ${ }^{6}$ It was around this time that Gregorio Vásquez’s grandparents arrived in Santa Fe de Bogotá.

By about 1625, American-born painters had taken over the market in the major centres in Latin America. ${ }^{7}$ This is not to say that artistic ties to Europe had weakened. In fact, the transatlantic trade of artwork continued and grew exponentially until the late eighteenth century. Among the most powerful early European artistic influences in many Latin American urban centres was the assimiliated blend of Italian and Flemish styles then prevalent in Seville. Flemish works poured into New Spain and South America through enterprising dealers like the Forchondt family, based in Antwerp, who exported prints and paintings to Seville and thence to the Americas. ${ }^{8}$ After about 1630, the work of Peter Paul Rubens (1577-1640) was well known throughout the viceroyalties. Later, Francisco de Zurbarán (1598-1664), who also acted as an exporter of Flemish and Spanish artworks, sent several major commissions to religious institutions in South America. The complicated impact Murillo had on the visual arts in the Americas has been clarified in recent studies, and his influence on Gregorio Vásquez has been noted throughout the literature on the Colombian painter. While Murillo himself had planned to travel to the New World in 1633, it is not clear that he ever undertook this trip. However, documents show his son Gabriel had arrived in Colombia by 1679, just as Vásquez's career began to flourish; on 8 June 1681, Gabriel was married in Bogotá to Antonia López Nieto. 9

While transatlantic trade and artistic transmission are crucial to understanding the development of colonial painting in the Spanish and Portuguese Americas, different styles and visual languages emerged in each centre of production, depending on many factors, including but not limited to, questions of patronage, the relative endurance of pre-Hispanic techniques, and the prevalence of Indigenous artists. For example, the predominant style of painting in Cuzco little resembles that which was produced in neighbouring Lima. Vásquez, who had trained in the studio of Baltasar de Figueroa, also of Sevillian origin, acquired an understanding of the painting of contemporary Seville that played a conspicuous role in his artistic development. To judge from his oeuvre, Vásquez was a sophisticated master of visual and iconographic synthesis. He also proved an adept judge of the Bogotá art market, which included both ecclesiastical and mercantile patrons, producing a consistent body of work for which demand never seemed to wane. 
Gregorio Vásquez: Man and Myth

Gregorio Vásquez de Arce y Ceballos is the most outstanding figure in hispano-american art of the colonial period. No other artist of that period can offer... a body of work that is greater in quantity, intrinsic merit, or enduring human significance. More prolific and consistent than the famous Echaves of New Spain...superior in technique and pictorial [quality] to the renowned Miguel de Santiago of Quito, with a gift incomparably higher than his predecessor and contemporaries.

Gabriel Giraldo Jaramillo (1944)

While few details are known of Vásquez's early life, he is hardly an obscure artist in his native Colombia. The first scholarly publication on the painter, Noticia descriptiva de algunos cuadros de Vásquez by José Manuel Groot, appeared in 1859, followed by a larger monograph by the same author later that year. ${ }^{10}$ Vásquez’s work was highlighted in major exhibitions in Bogotá in 1886 and 1914, and following Francisco Pizano Restrepo's seminal catalogue of 1926, a generation of noteworthy Colombian scholars continued to publish on Vásquez and his oeuvre in the mid-twentieth century. ${ }^{11}$ This group of historians included Gabriel Giraldo Jaramillo, Guillermo Hernández de Alba, Francisco Gil Tovar, and the renowned Spanish scholar, Diego Angulo Iñíguez. While Vásquez has enjoyed continuous popularity in Colombia, even gracing Colombia's postage stamps from the early and mid-twentieth century, he has remained all but neglected by North American art historians until recently. ${ }^{12}$ Since their inclusion in the 1999 exhibition, Los Siglos de Oro en los Virreinatos de América, 1550-1700 (Museo de América, Madrid), Vásquez's works have been shown in several exhibitions in the United States, Mexico, and Canada, including those organized by the Philadelphia Museum of Art and the Cantor Arts Center (Stanford University, California), both in 2006.13

As Luisa Elena Alcalá notes, the early historiography of Gregorio Vásquez is marked by personal mythology and a tendency to define the artist within the framework of an idealized national character. ${ }^{14}$ The propensity to claim an artist as evidence of national cultural excellence was prevalent on both sides of the Atlantic from the nineteenth century until as recently as the 1970s. Such an introspective regional vision has occasionally caused misidentifications of artists in Spain and its American viceroyalties, as was the case in the early twentieth century, when works by Jusepe de Ribera were mistakenly attributed to the more definitively Spanish Murillo. In the case of Vásquez, his contemporaries were avid consumers of his specifically Sevillian style, while in the nineteenth and early-twentieth centuries, post-Bolivar intellectuals and collectors sought value in promoting the artist and glamourizing his biography to ensure his entry into the pantheon of the world's greatest artists. In the process, a number of overly optimistic attributions may have been made in order to capitalize on the artist's renown. The rediscovery and conservation of the Denver panels has helped to clarify some of the distinctions between master and studio.

A host of undisputed genealogical information adds context to Vásquez's artistic development and later biography. The artist's grandfather and great-grandfather left Seville for New Granada, arriving in Cartagena de Indias sometime around 1598. The artist's father, Bartolomé Vásquez de Arce y Varo, was most likely born in Bogotá around 1600. Gregorio was born in 1638, about eight years after his older brother, Juan Bautista, and two years before his younger brother, Diego. In 1665, Gregorio married a native of Bogotá, Jerónima Bernal Esguerra, and together they had four children: Diego (b. 1667), Feliciana (b. 1675), Bartolomé Luis (b. 1680), and Pedro (1683-1746). Diego and Feliciana were both documented painters, while Pedro was listed as a silversmith. 15

Vásquez’s principal artistic training took place in the Bogotá workshop of Baltasar de Figueroa, son of Gaspar, the founding patriarch of an important family of painters also from Seville. While receiving what must have been a competent education in the art of painting, Vásquez also had access, in the Figueroa studio, to many illustrated books and to around 1,800 prints. ${ }^{16}$ The story of Vásquez's expulsion from the Figueroa studio for "correcting" one of the master's works may be apocryphal, but in any event Vásquez had his own workshop by 1658, around the time of his earliest signed paintings. ${ }^{17}$ His impressive, broad understanding of artistic trends in Golden Age Spain, likely first cultivated within the Figueroa studio and its library of engravings, was crucial to his working method and technical development. Prints and drawings would become fundamental to his own workshop, which he organized around his nuclear family, as was common throughout early modern Spain and Latin America.

Early scholars speculated that Vásquez may have visited his ancestral home in Seville, yet no evidence has come to light that he ever crossed the Atlantic; furthermore, Bogotâs thriving Sevillian community and its active commercial ties to the Spanish metropolis probably obviated the need for such a dangerous and expensive trip. Gabriel Murillo brought works of art, including paintings, from Seville, though nothing by his famous father is listed in his 1700 inventory. However, Gabriel's brother Gaspar sent two paintings by the elder Murillo to Bogotá following the master's death in 1682.18 The constant influx of friars, Jesuits (with whom Vásquez had studied as a boy), churchmen from Spain and Italy, along with merchants (and presumably artists) from Seville and elsewhere, meant that Bogotá, like Mexico City, was closely connected to contemporary artistic 


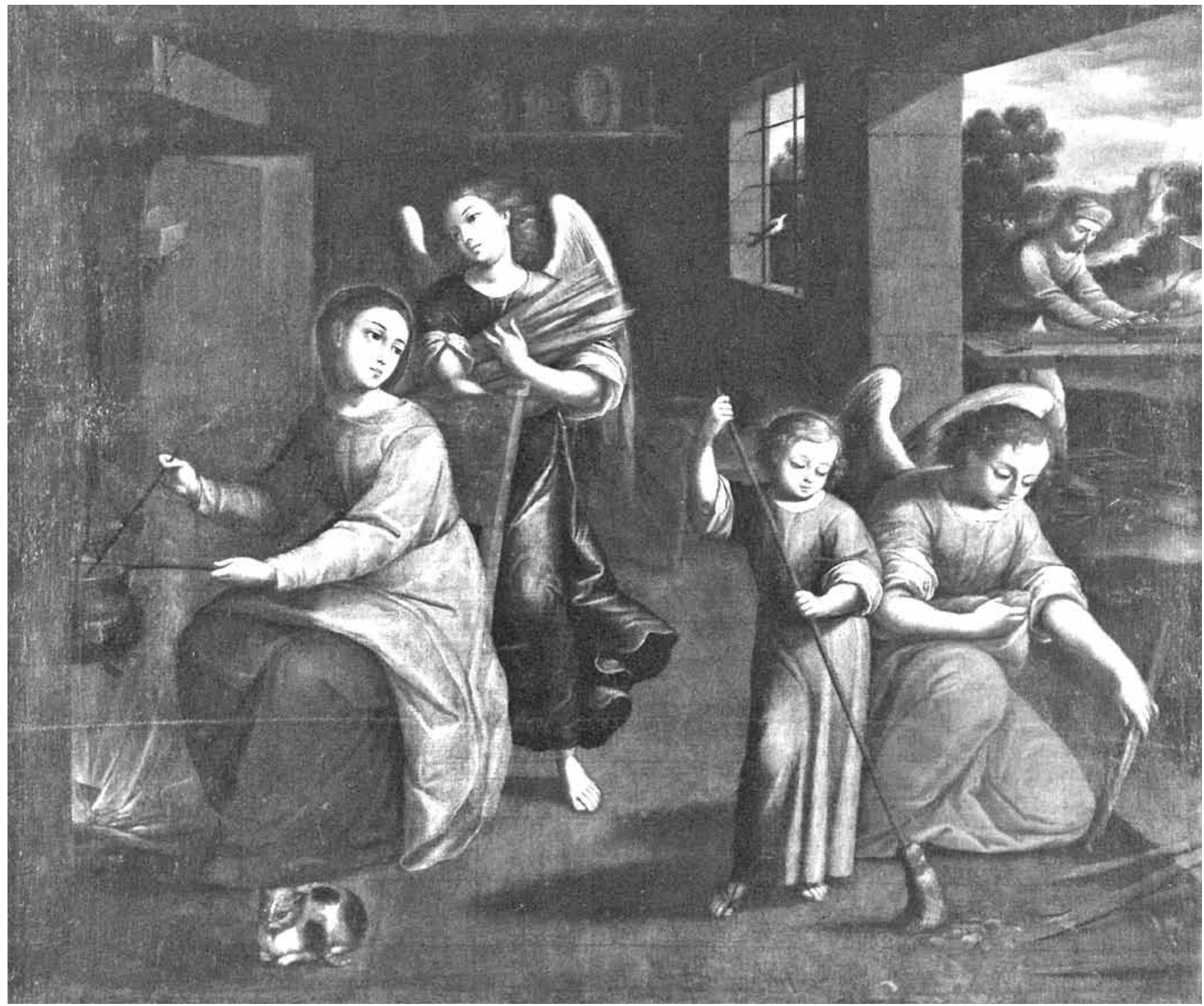

Figure I. Gregorio Vásquez de Arce y Ceballos, House of Nazareth, ca. 1685. Oil on canvas, 158 × $178 \mathrm{~cm}$. Museo de Arte Colonial, Bogotá (photo: Alberto Sánchez / Museo Colonial y Museo Santa Clara).

and cultural trends in Europe. Gregorio Vásquez, to judge from his vast extant oeuvre and its stylistic consistency, was among the most adept artists at synthesizing these European influences for a growing clientele who leaned unequivocally towards Sevillian taste. We find a powerful example of this affinity in his 1685 masterpiece House of Nazareth (fig. 1), especially when compared with Murillo's earlier treatment of a similar subject in his Holy Family with the Infant Saint John the Baptist (fig. 2). Vásquez's scene shares Murillo's sense of tranquillity, and adds several quotidian details that foster a human connection with the viewer, such as the cat warming itself by the hearth and the Christ Child helping sweep the floor. Even the two angels present are assisting the holy family in their chores. The image encapsulates Vásquez's artistic vision, which was based on sound draftsmanship, sophisticated naturalism, convincing still-life and landscape details, and a thorough understanding of the visual language of the Counter-Reformation.

Draftsmanship lay at the heart of Vásquez's creative process. In drawings, he was able to explore facial types, anatomy, and complex poses with a remarkable economy of line. Many of his drawings are characterized by bold contour lines and feature single-figure or small group studies that may be found 


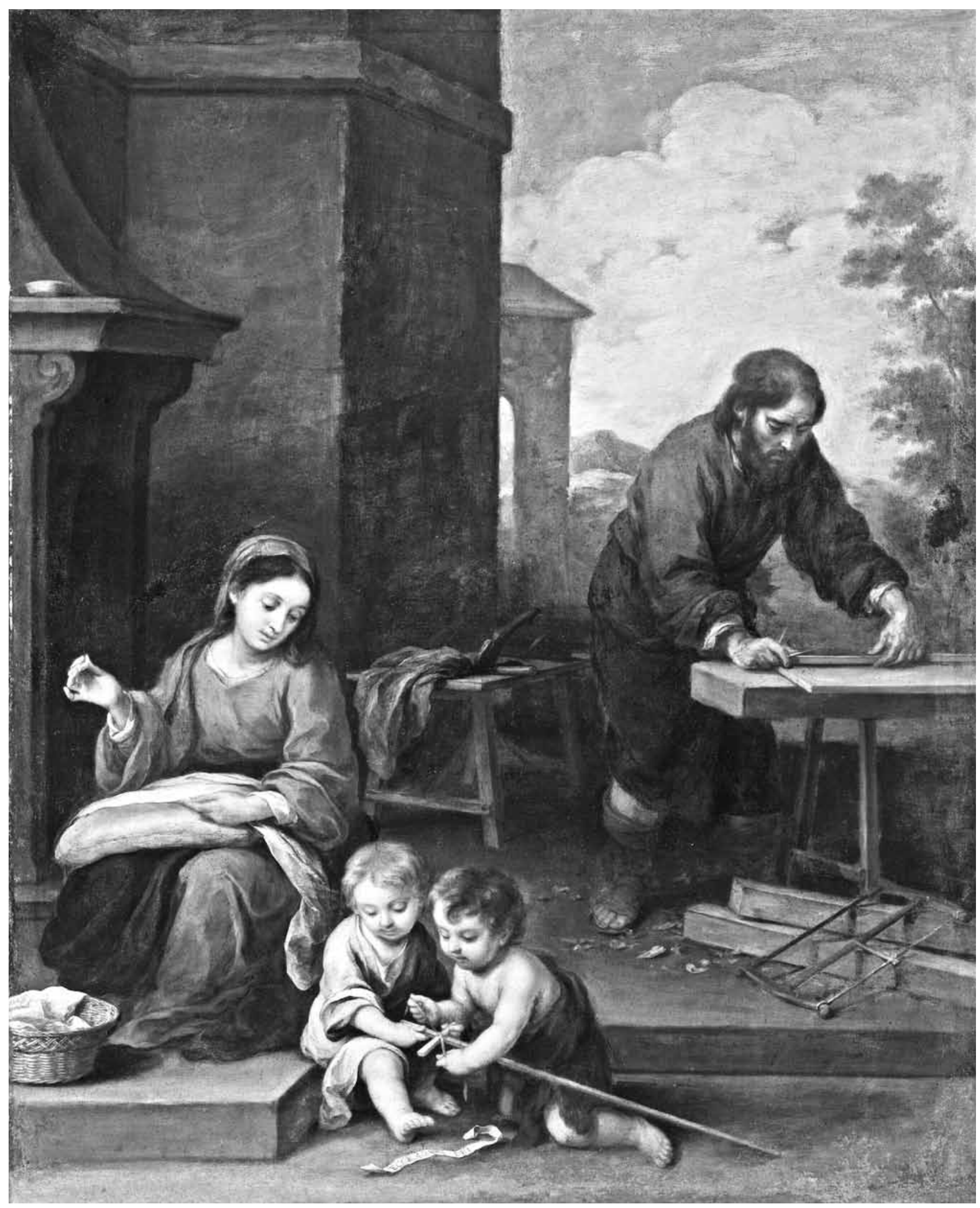

Figure 2. Bartolomé Esteban Murillo, Holy Family with the Infant Saint John the Baptist, 1655-59. Oil on canvas, $156 \times 126 \mathrm{~cm}$. Fine Arts Museum, Budapest (photo: Fine Arts Museum, Budapest). 
in finished paintings. This was an unusual approach during this period in the Spanish colonies, contrasting most starkly with the lack of extant drawings by Vásquez's prolific contemporary in Mexico, the idiosyncratic master Cristóbal de Villalpando (c. 1649-1714). The notion that artists in Latin America did not produce or employ drawings may be a misconception arising simply from survival rates and other accidents of history; perhaps for this reason studies of draftsmanship in early modern Latin America are also all but absent from the scholarly literature. In its consistent use and production of pen drawings, Vásquez’s Bogotá workshop superficially resembles Murillo's in Seville, though there is little stylistic similarity in their drawings; we might speculate that the practice was modelled more closely on that of Vásquez's master, Figueroa.

\section{The Denver Panels}

The Temptation of Saint Thomas Aquinas is the largest of the four panels in the Denver Art Museum (fig. 3). It depicts an episode from the established hagiography of the Dominican theologian as compiled by Jacobus de Voragine in the Golden Legend and elsewhere. The event occurred early in Thomas's spiritual life, around 1250, when he decided, against his noble family's wishes, to enter the Dominican Order of Preachers. Thomas's mother intervened: she had his two brothers hire a beguiling prostitute to seduce her son, in an attempt to end his Dominican novitiate. Wielding a blazing torch, Thomas chased the young woman from his quarters. He was rewarded for his chastity with a visit from the Virgin Mary and Christ Child and a symbolic chastity belt given to him by two angels. The angels' bestowal of the belt, not readily legible before the painting's recent cleaning, provides the scene's iconographical and dramatic climax. The saint's resolute chastity is paralleled by his own persistence in joining the Dominican order in the face of his family's opposition. Vásquez's panel presents Thomas as an exemplum virtutis to be emulated by faithful viewers, and especially by fellow Dominican novices or seminarians contemplating the devotional life. Thomas Aquinas went on to become one of the most renowned Roman Catholic theologians, a doctor of the Church, and a seminal figure in modern Western thought. Though an uncommon topic in Spanish and Latin American painting at the time, the episode is now often encountered among Hispanists, mainly as a result of Diego de Velázquez's famous treatment of the same scene in a large canvas for the Dominican college in Orihuela, Spain (Museo Diocesano).

The Denver painting's composition is based on an engraving by Benoît Thiboust (French, active in Italy from c. 1655) after Giacinto Calandrucci (Italian, 1646-1707), from whom Vásquez took his preparatory drawing of the figure of Thomas Aquinas (fig. 4). The inscription states that the print was pro- duced in Rome during the sixteen-month reign of Pope Alexander VIII (1689-91) to commemorate the founding of the Dominican College of San Fernando in Quito. ${ }^{19}$ Thiboust's graphic work must have been available in New Granada as there are other instances of Vásquez's use of his prints, including a Saint Rose of Lima (fig. 5) adapted from an image published in Serafino Bertolini's La Rosa peruana of 1666.20 The iconographic and commemorative ties to South America that these works share, along with others by Thiboust, indicate that they would have found a ready audience in New Granada and Peru.

While the identification of Thiboust's print as Vásquez's pictorial source has much scholarly value, including its determination of the painting's terminus post quem to about 1690, of greater significance is how the artist employed the print in his artistic modus operandi. The widespread use of European prints by artists in Spain's American colonies is well studied: most notable is the work of the late historian of Colombia, Santiago Sebastián;21 Sabine MacCormack has recently made important contributions to our understanding of the use of print sources in Lima, specifically a series of engravings by Schelte á Bolswert employed by Basilio Pacheco;22 likewise, Suzanne L. StrattonPruitt has identified numerous engraved sources for viceregal paintings in Quito. ${ }^{23}$ In the case of Vásquez's employment of such models, we are aided by the existence of a partially painted impression on paper of The Temptation of Saint Thomas Aquinas by Thiboust in the Denver Art Museum, which was acquired by Daniel Stapleton at the same time he bought the Vásquez panels. ${ }^{24}$ In spite of its poor condition and the clumsiness of the application of the oil paint, this object sheds a great deal of light on the practices of the Vásquez workshop. The painted print appears to have been done by a studio hand at an early stage of his or her apprenticeship. 25

At some point, the master himself produced the study drawing in sepia ink of the central figure of Saint Thomas Aquinas (fig. 4). With its clear, bold lines and large format, it appears to have served as a model for the painting's composition, while surplus impressions of Thiboust's engraving could have been used for training exercises and further drawing studies. Vásquez is unique among Spanish Colonial painters in having a large extant corpus of autograph drawings (all in the collection of the Museo de Arte Colonial, Bogotá), many of which may be identified as models for his compositions. Vásquez's drawings are notable for their large size, clearly defined outlines, and lack of subtle shading. ${ }^{26}$ In short, they are bold and didactic-the type of drawing a studio assistant (or indeed, the master) might use as a guide in the execution of larger painted compositions. Stylistically, the drawings do not appear to have been executed as independent works of art, and they lack the finish and shading of drawings by Murillo or Rubens. Like many of Rubens's drawings, Vásquez's appear to be sketches with well-defined outlines, 


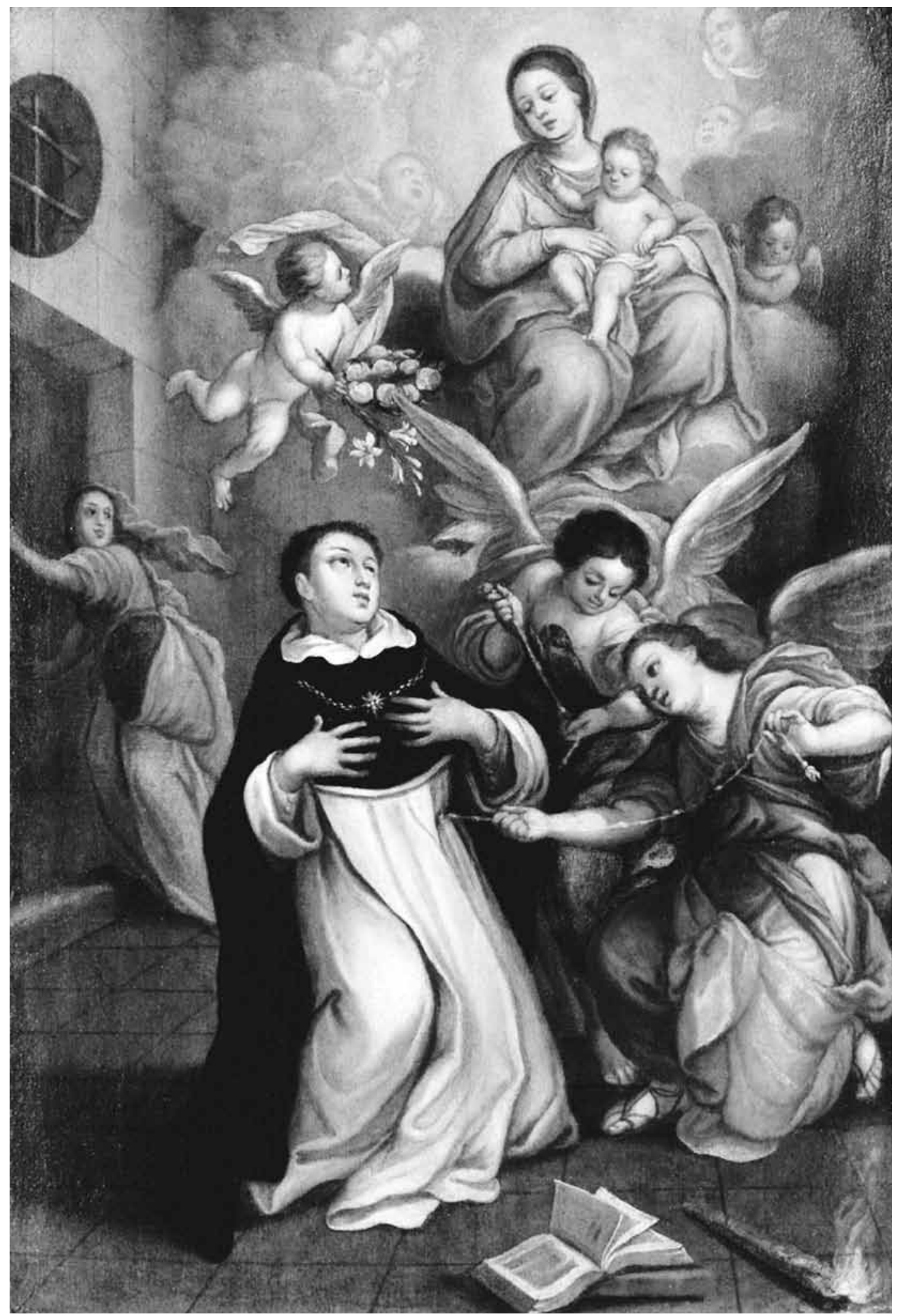

Figure 3. Gregorio Vásquez de Arce y Ceballos, The Temptation of Saint Thomas Aquinas, 1690s. Oil on paper on wood panel, $52.7 \times 36.8 \mathrm{~cm}$. Denver Art Museum, Gift of the Stapleton Foundation of Latin American Colonial Art, made possible by the Renchard Family (photo: Jeff Wells, Denver Art Museum). 


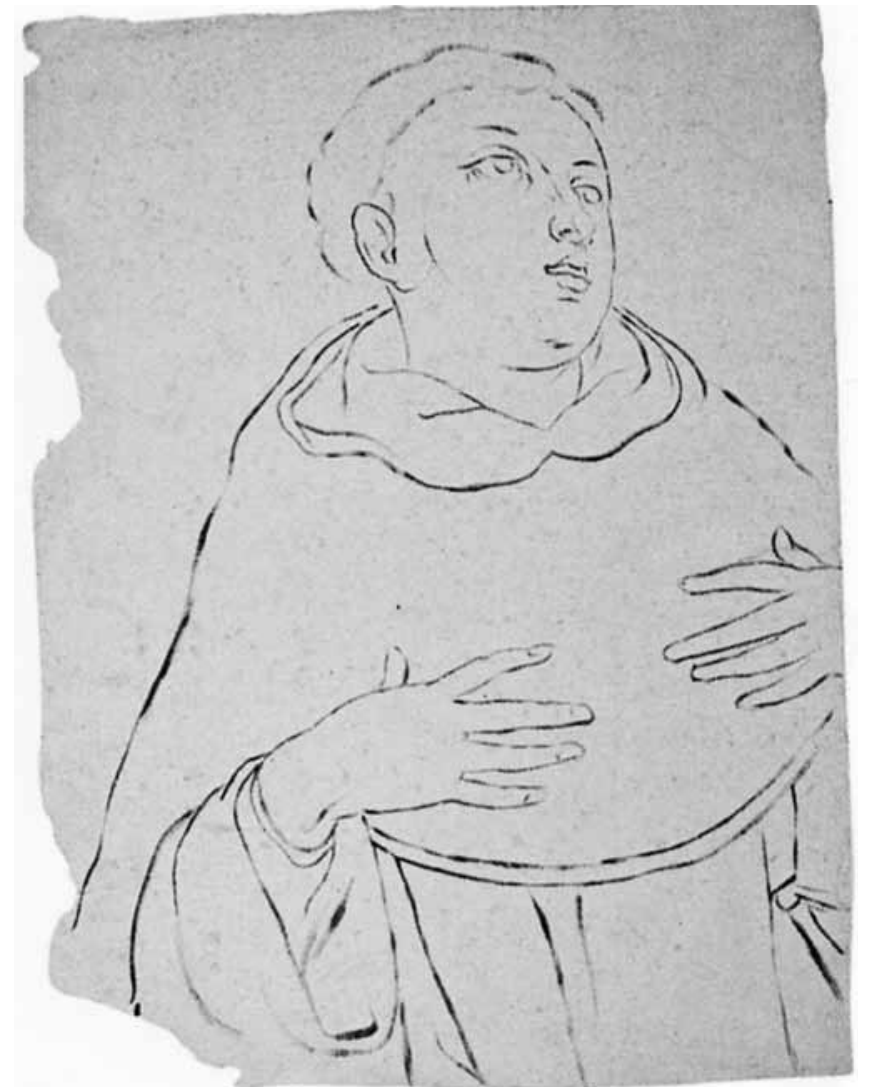

Figure 4. Gregorio Vásquez de Arce y Ceballos, Saint Thomas Aquinas, 1690s. Sepia ink on paper, $42 \times 31 \mathrm{~cm}$. Museo de Arte Colonial, Bogotá (photo: Museo Colonial y Museo Santa Clara).

but without the Flemish master's various washes and highlights. Vásquez's drawings were ideal for copying and tracing (some drawings may themselves even be tracings). During conservation treatment of the Thomas Aquinas panel, it was discovered that the painting's principal support is paper affixed to the wood panel, suggesting that an underdrawing or "story-board" technique was employed. Because most of Vásquez's sketches are for single figures and anatomical details such as hands and feet, rather than full compositions, it may be that the master's intention was to impose a level of quality control on the most difficult elements of large-scale commissions.

The second panel in Denver (fig. 6) that may now be attributed to Gregorio Vásquez depicts the founder of the Dominican monastic order, Domingo Félix de Guzmán (1170-1221), who was born in the province of Burgos, Spain, and canonized in 1234. He is shown contemplating Scripture as he prepares for a peaceful and dignified death in the Italian countryside. Following conservation treatment in 2012, the painting was found to exhibit brushwork and palette consistent with The Temptation of
Saint Thomas Aquinas. ${ }^{27}$ After cleaning, details such as the rosary beads, an important attribute of Dominic's iconography, became readily visible. The Saint Dominic panel, which is not signed, may be attributed to the master, based in part on stylistic comparisons to other known works by the artist, but also on its close similarity to a panel by Vásquez of the same subject and composition and nearly identical dimensions in a private collection in Colombia. ${ }^{28}$ The very slight (about $1 \mathrm{~cm}$ ) difference in the width of the two panels is explained by the fact that the Denver Saint Dominic shows signs that it was trimmed on the right side, presumably to fit a frame. The painting probably dates from the 1680s, when Vásquez was occupied with commissions for the church and monastery of Santo Domingo in Bogotá. 29

Bolstering the credibility of the attribution is the landscape in the background of the composition and the rendering of the lilies and book in the foreground. A similar treatment of

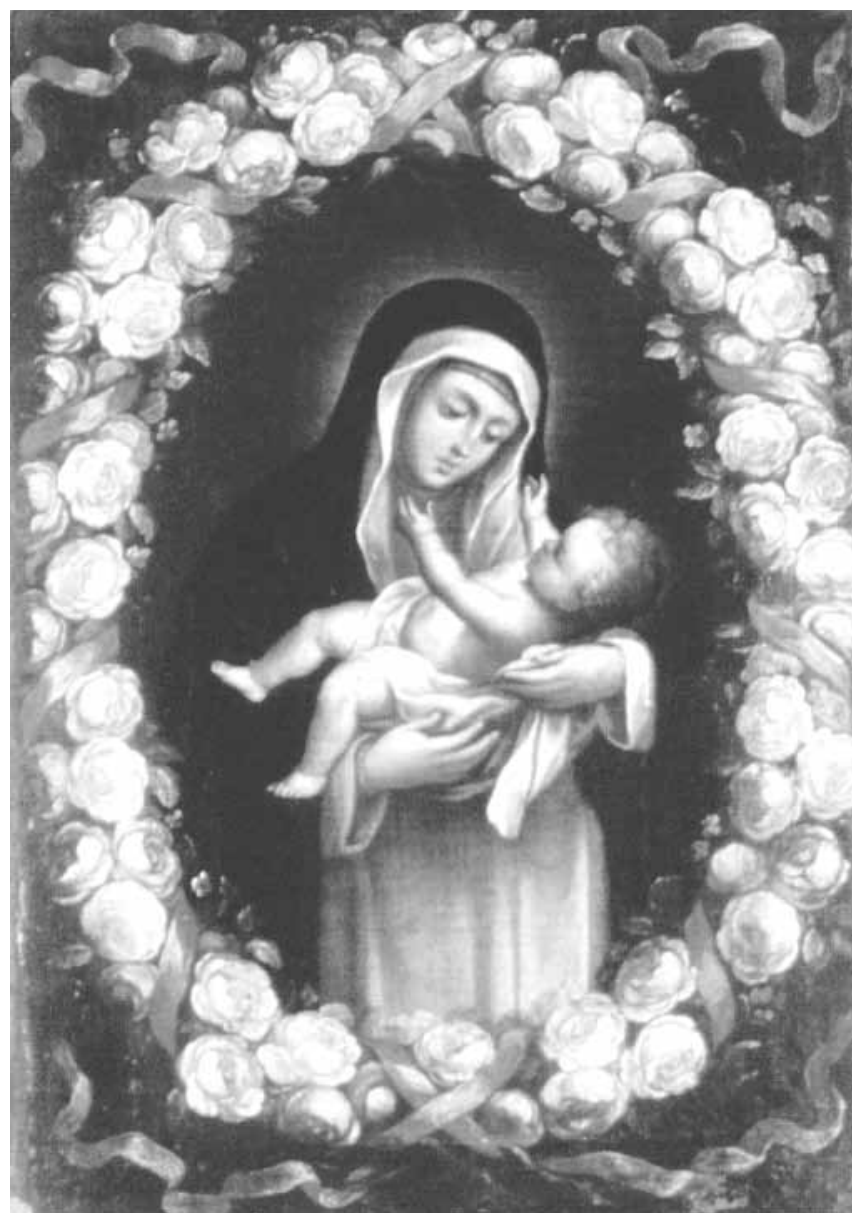

Figure 5. Gregorio Vásquez de Arce y Ceballos, Saint Rose of Lima, ca. 1680. Oil on canvas, $45 \times 31 \mathrm{~cm}$. Museo de Arte Colonial, Bogotá (photo: Museo Colonial y Museo Santa Clara) 


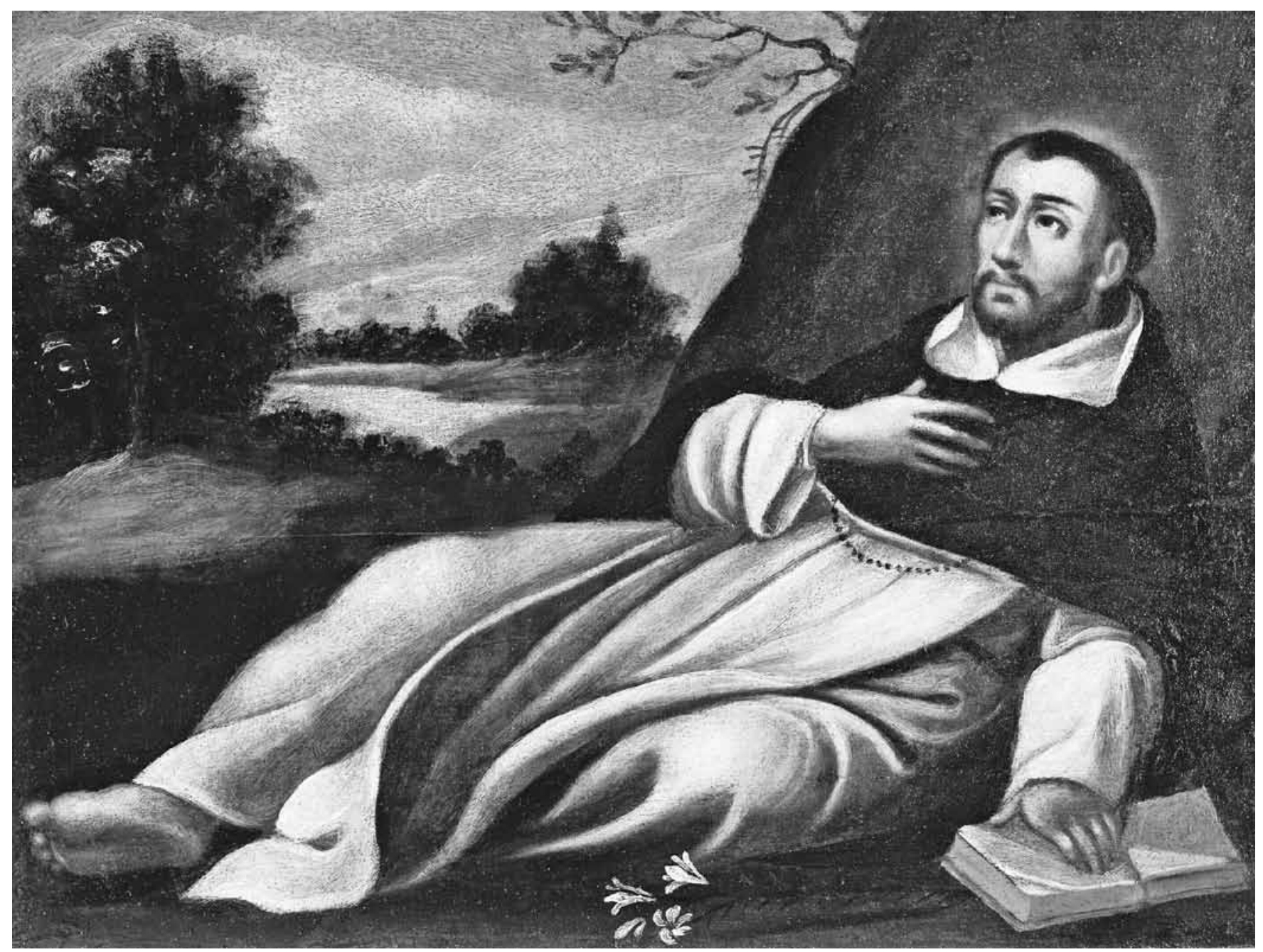

Figure 6. Gregorio Vásquez de Arce y Ceballos, The Death of Saint Dominic, 1680s. Oil on wood panel, $20 \times 22 \mathrm{~cm}$. Denver Art Museum, Gift of the Stapleton Foundation of Latin American Colonial Art, made possible by the Renchard Family (photo: Jeff Wells, Denver Art Museum).

landscape and still-life elements is found in many works by Vásquez, most notably perhaps in his Institution of the Rosary, in which the Virgin and Child appear before Saints Dominic and Anthony of Padua. ${ }^{30}$ In this work, the landscape is painted in the long, sweeping strokes of diluted pigment that we find in the Saint Dominic panel. Likewise, the lilies and book of Scripture are treated with great similarity in both works. The white petals of the flower are nearly diaphanous, deftly rendered with one or two touches of the brush. In the landscape and sky of both paintings, the artist makes use of the reddish-pink ground, leaving it visible to create a soft atmosphere and sense of depth. The application of paint is especially sophisticated in the foliage on the left side of the Saint Dominic painting, bearing a close resemblance to the handling of the trees and leaves in Vásquez's large Saint
Francis Xavier (fig. 7). In both works, the artist uses a technique of single dabs of white impasto to convey a naturalistic light source and sense of volume in the trees. Likewise, a comparison to the nude figure of Adam in Vásquez's Creation of Eve, ${ }^{31}$ who is depicted in a similar reclining position in the immediate foreground, reveals further stylistic consistencies, such as the modelling of the feet, with highlighted soles and pronounced heels, which is nearly identical in both, and the languid left hand, the two middle fingers of which rest one on top of the other. Details like these are also found in several of Vásquez's study drawings of hands and feet, apparently taken from life. 32

The Denver Art Museum's panel depicting The Virgin Mary in Prayer (fig. 8) is a variation of Vásquez's work in the Sagrario chapel. The Sagrario commission, which comprised more than 
BROWN | Gregorio Vásquez de Arce y Ceballos in Viceregal Colombia

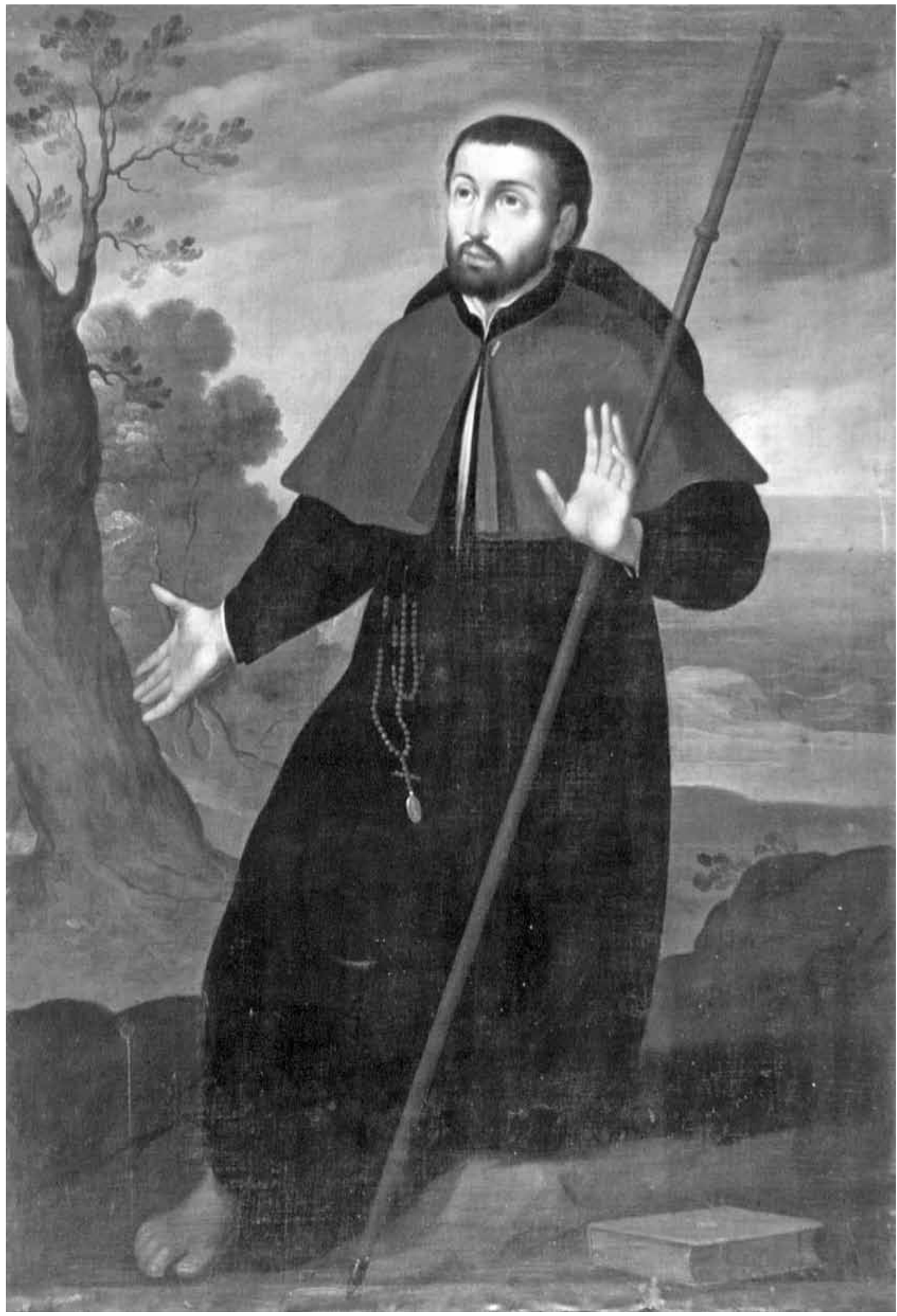

Figure 7. Gregorio Vásquez de Arce y Ceballos, Saint Francis Xavier, $1680-1700$. Oil on canvas, $153 \times 104 \mathrm{~cm}$. Museo de Arte Colonial, Bogotá (photo: Museo Colonial y Museo Santa Clara). 


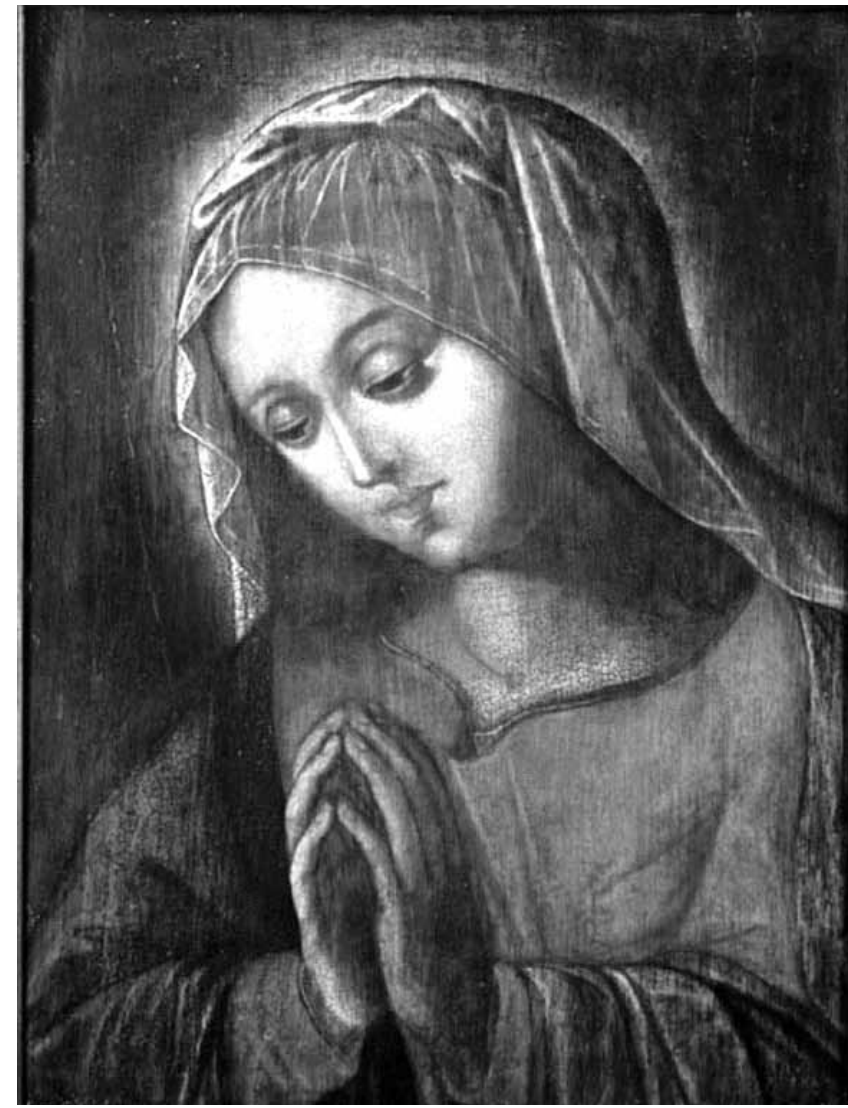

Figure 8. Workshop of Gregorio Vásquez de Arce y Ceballos (possibly Juan Bautista Vásquez), The Virgin Mary in Prayer. Second half of the seventeenth century. Oil on wood panel, $49.5 \times 34.6 \mathrm{~cm}$. Denver Art Museum, Gift of the Stapleton Foundation of Latin American Colonial Art, made possible by the Renchard Family (photo: Jeff Wells, Denver Art Museum).

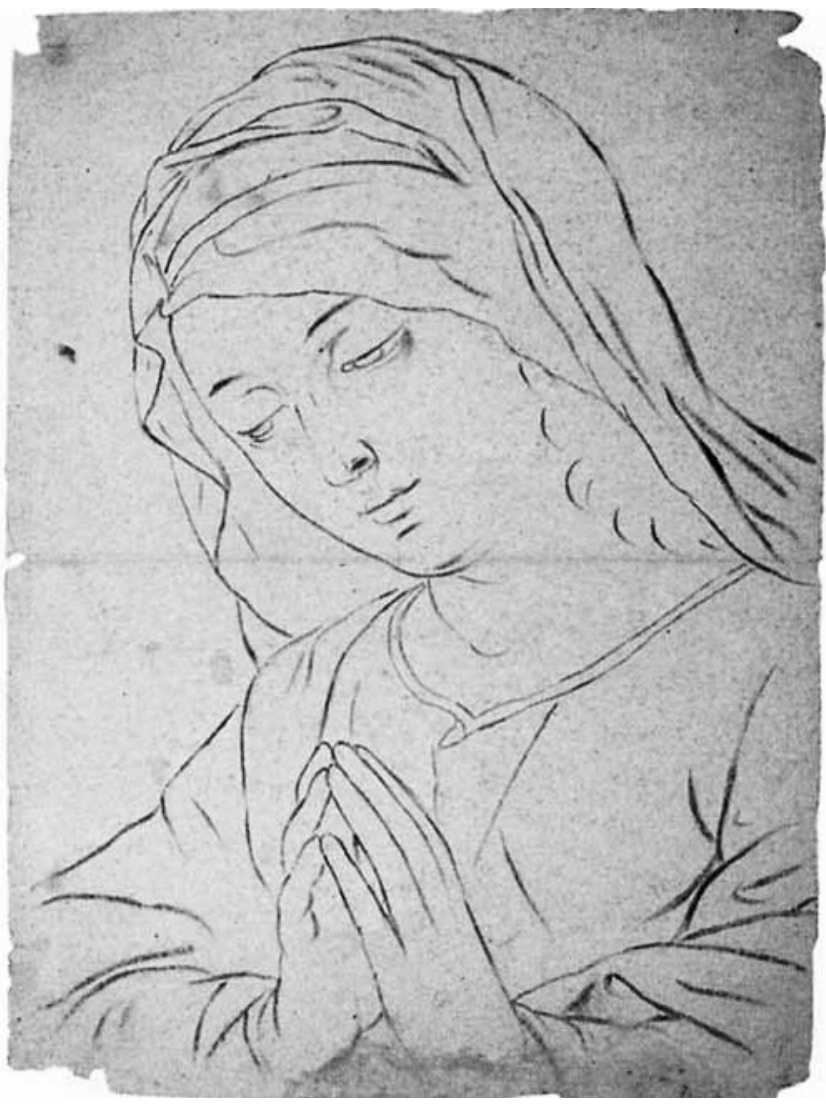

Figure 9. Gregorio Vásquez de Arce y Ceballos, The Virgin Mary in Prayer. Sepia ink on paper, $42 \times 31 \mathrm{~cm}$. Museo de Arte Colonial, Bogotá (photo: Museo Colonial y Museo Santa Clara). fifty paintings, occupied Vásquez for much of his career. ${ }^{33}$ In order to meet the demands of such ambitious projects, Vásquez likely employed his brother, Juan Bautista, and later his own children, Feliciana and Diego, as workshop assistants. The Denver Art Museum's Virgin in Prayer is a competent realization of this workshop, which produced at least nine extant versions on wood panel of this composition, mostly of similar dimensions. 34 The panels in Denver and the Sagrario, which show a bust-length Virgin Mary with hands clasped elegantly in prayer, correspond to Vásquez's preparatory drawing (fig. 9). The Denver painting clearly relies on the drawing for stylistic and compositional details, including the heavy-lidded eyes, carefully modelled chin, clearly delineated nose structure, and deft brushstroke that defines both the Virgin's neck and her suprasternal notch. Most of the drapery folds also follow the general outlines of the drawing. However, in details such as the pursed lips and overall fall of the headdress, the Denver panel more closely resembles the master's original painting. This suggests that the painting's author had direct knowledge of both works and that the picture was probably executed under the master's watchful eye.

As Pizano Restrepo recognized as early as 1921, Vásquez had access to a broad range of European painting through print sources, as well as works copied after Italian and Spanish masters. Among these, works by Guido Reni, Rubens, Zurbarán, and Murillo figure prominently in Vásquez's oeuvre. ${ }^{35} \mathrm{His}$ Virgin in Prayer is modelled on works by the Italian Giovanni Battista Salvi da Sassoferrato (1609-85). Sassoferrato produced at least seven so-called Northern Headdress Madonnas (named for their similarity to Albrecht Dürer's work), a replica of which arrived in Colombia during the viceregal period. ${ }^{36}$ It is plausible that Vásquez employed the Sassoferrato copy as the model for his drawing, which in turn spawned the many workshop replicas that must have been in high demand in colonial Colombia. 
BROWN | Gregorio Vásquez de Arce y Ceballos in Viceregal Colombia

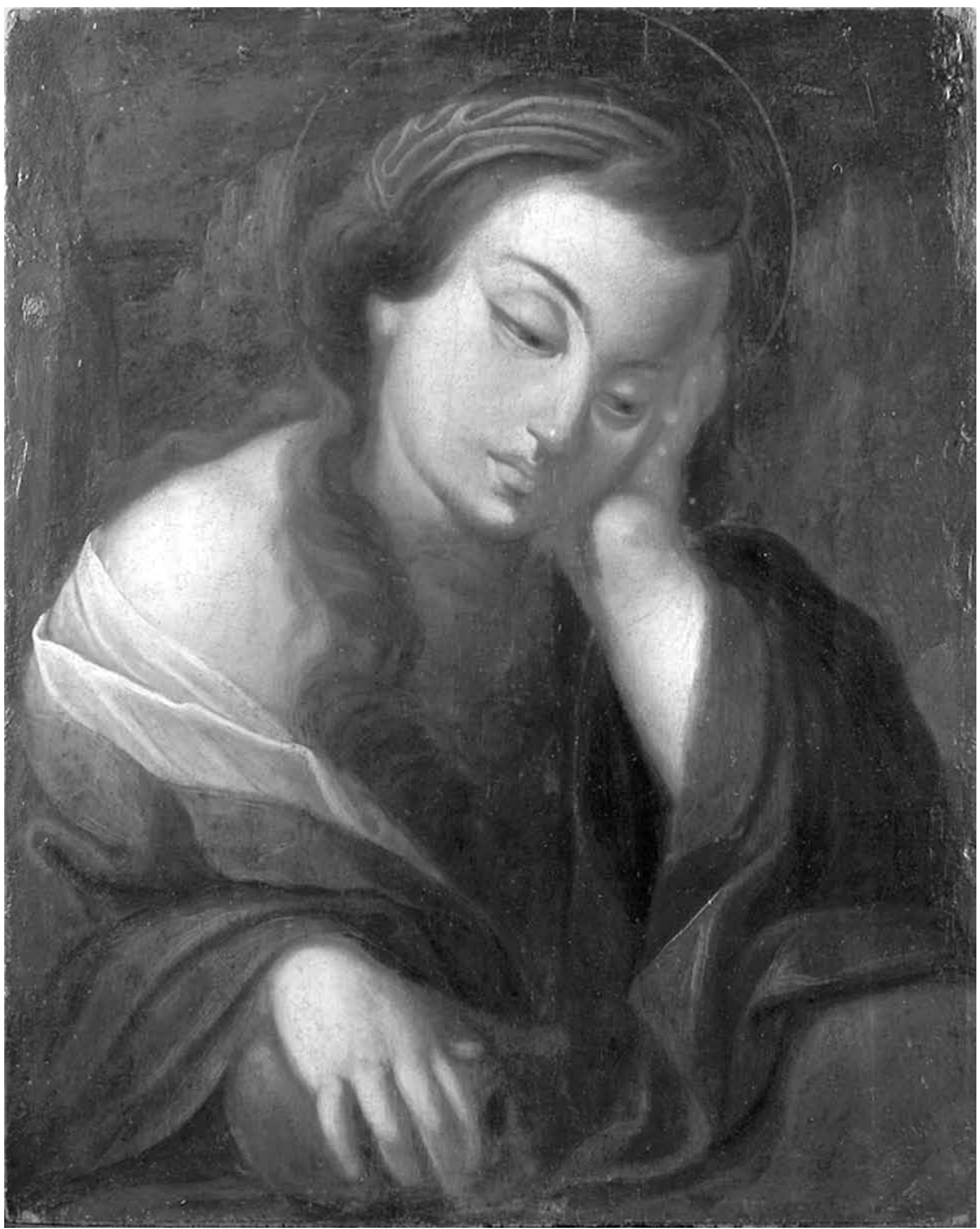

Figure 10. Workshop of Gregorio Vásquez de Arce y Ceballos, The Penitent Mary Magdalene, second half of the seventeenth century. Oil on panel, $33 \times 27.9 \mathrm{~cm}$. Denver Art Museum, Gift of the Stapleton Foundation of Latin American Colonial Art, made possible by the Renchard Family (photo: Jeff Wells, Denver Art Museum). 
The fourth panel in Denver that may be associated with the workshop of Gregorio Vásquez is The Penitent Mary Magdalene (fig. 10). While no drawing has surfaced that may be associated with it, the composition relies entirely on a larger version signed by Vásquez and dated August 1680.37 The iconography of this image is notably austere: the Magdalene sinks her head in her left hand in an echo of Dürer's Melencolia I (1514), while her right hand rests atop a human skull. There is very little peripheral detail, few still-life elements besides the skull and a book of Scripture that symbolize the Magdalene's contemplative inner struggle. This is in stark contrast to later examples of the same subject by Andean painters, in which the viewer is treated to opulent visual displays of jewellery, textiles, glassware, and other luxuries, as the Magdalene forsakes the material world. 38 Vásquez's image is much closer in spirit to Murillo's Magdalenes, in which the figure is a pared-down Counter-Reformatory model of the sacrament of penance.

In his iconography, Vásquez may have been informed by prints and illustrated chapbooks, which were often produced and exported by the religious orders in Rome. ${ }^{39}$ The presence of Italian painters in South America is well studied; Angelino Medoro (1567-1633) enjoyed the patronage of both the Dominicans and Franciscans in Bogotá and Tunja before moving on to Peru. It is possible an artist like Medoro or his monastic patrons could have brought this type of Magdalene to New Granada in the form of chapbooks or other printed material. The cleaning of the Magdalene panel in the Denver Art Museum confirmed that the paint surface was in good condition, but it also revealed the figure's awkward anatomy and flawed, inconsistent modelling. It is surely not the work of the master, nor is it likely to have originated from the hand of a mature workshop assistant. However, this should not detract from the work's intrinsic art-historical value, as it suggests a thriving workshop in which many artists operated at varying stages of training. It would be tempting to associate this work with the juvenilia of Diego, Vásquez's eldest son, who would have been in his mid-teens when his father was composing the original. This must remain speculation, however, as no surviving painting has yet been linked to Diego, or for that matter to his younger sister, Feliciana.

\section{Conclusions}

Gregorio Vásquez de Arce y Ceballos's commercial success, as indicated by the quantity of his commissions and the prestige of his patrons, seems to have been cut short in 1701 by an extended incarceration on charges of accessory to rape. 40 Whatever the merits or political motivations of these charges, the canons of the cathedral in Bogotá saw fit to bury Vásquez within the sanctuary upon his death in 1711, suggesting his reputa- tion had survived intact. As for the four rediscovered panels in the Denver Art Museum, two-The Temptation of Saint Thomas Aquinas and The Death of Saint Dominic - appear to be the work of the master himself. The other two-The Virgin Mary in Prayer and The Penitent Mary Magdalene-are here ascribed to two different hands in the Vásquez studio. All four are variants of compositions employed by Vásquez in other paintings, and two, the Thomas Aquinas and the Virgin in Prayer, also correspond closely to extant preparatory drawings of undoubted authenticity. What can these paintings tell us?

First, the panel paintings in Denver indicate that Vásquez's studio practice was based on a proto-academic notion of the primacy of draftsmanship, which appears to have been highly unusual in viceregal Latin America. His print collection did not just provide compositional or iconographical models; it now appears that he encouraged his students to paint directly on surplus impressions and that he used them himself for figure drawings, which in turn served as models during the execution of both autograph masterpieces and workshop paintings. Second, Vásquez's production of profitable copies and variants, often carried out by studio assistants, would certainly have insured his family's financial security, but it also points to a thriving art market in Bogotá. While the importation of thousands of Flemish paintings (often copies) to the Spanish American colonies continued, the demand for Vásquez's work flourished, resulting in the production en masse of many small-scale variants and copies. Lastly, this brief study of Vásquez and his career brings up questions regarding the status of the artist in early modern Latin American society. Vásquez was held in high esteem by his patrons during his lifetime, by the cathedral chapter at the time of his death, and by artists and writers in Colombia in the centuries after his death. His vast oeuvre, fuelled by a fertile artistic imagination that was thriving on both sides of the Atlantic, is ripe for further scholarship, and the more general issue of global artistic transmission in the Spanish world warrants broader consideration. In tying together some of these varied threads of national art-historical studies, we find that Gregorio Vásquez's world was much smaller and more connected than we had previously imagined.

\section{Acknowledgements}

I would like to thank the guest editors, Aléna Robin and Luís de Moura Sobral, for their advice during the preparation of this article. I gratefully acknowledge the assistance provided by Denver Art Museum staff, including curator Donna Pierce, Julie Wilson Frick, Sarah Cucinella-McDaniel, and paintings conservator Cynthia Lawrence. My thanks also to my colleagues Alicia Lubowski-Jahn, Luisa Elena Alcalá, and Lisa Duffy-Zeballos. 


\section{Notes}

1 The essential source on the artist is Roberto Pizano Restrepo, Gregorio Vásquez de Arce y Ceballos, 2nd ed. (Bogotá, 1985). This edition includes a reprint of Restrepo's 1926 catalogue, along with a prologue, notes, and an updated catalogue raisonné by Francisco Pizano de Brigard and Fernando Restrepo Uribe.

2 For Stapleton's biography and a selection of the works he collected, see Michael A. Brown, "D. C. Stapleton: Collecting Spanish Colonial Art in Colombia and Ecuador from the Gilded Age to the First World War," in The Arts of South America, 1492-1850, ed. Donna Pierce (Denver, 2010), 169-224.

3 Clara Bargellini, "Painting in Colonial Latin America," in The Arts in Latin America: 1492-1820, ed. Joseph J. Rishel and Suzanne Stratton-Pruitt (Philadelphia, 2006), 324.

4 Luisa Elena Alcalá, “Where do we go from here? Themes and Comments on the Historiography of Colonial Art in Latin America," in Art in Spain and the Hispanic World: Essays in Honor of Jonathan Brown, ed. Sarah Schroth (London, 2010), 324.

5 Luis Eduardo Wuffarden, “Mirar sin envidia'. Emulación, diferencia y exaltación localista en la pintura del virreinato del Perú," in Pintura de los Reinos: identidades compartidas. Territorios del mundo hispánico, siglos XVI-XVIII, Juana Gutierrez Haces et al., ed., (Mexico City, 2008), vol. 2, 643.

6 Carl Brandon Strehlke, "Angelino Medoro," in The Arts in Latin America, ed. Rishel and Stratton-Pruitt, 533.

7 Jonathan Brown, "Pintura de los Reinos: Introducción," in Haces, ed., Pintura de los Reinos, vol. 1, 19.

8 Brown, "Pintura de los Reinos," 18. It should be noted here that the extensive bibliography of art historian Santiago Sebastián López, a Spaniard who lived in Bogotá in the 1960s before returning to Spain, is foundational for the study of print sources in Colombia, as well as elsewhere in Latin America and Spain. See Alcalá, "Where do we go from here?," 335.

9 See Guillermo Hernández de Alba, "Gabriel Murillo, el hijo del inmortal sevillano," in Teatro del Arte Colonial (Bogotá, 1938).

10 See José Manuel Groot, Noticia biográfica de Gregorio Vásquez y Ceballos, pintor granadino del siglo XVII (Bogotá, 1859). See also Luisa Elena Alcalá, ed., Los siglos de oro en los virreinatos de América 1550-1700 (Madrid, 1999), 326.

11 See Restrepo, Gregorio Vásquez, 329-31.

12 Among the notable recent publications produced in Colombia, those of the Instituto Colombiano de Cultura stand out, such as the comprehensively illustrated Gregorio Vásquez de Arce y Ceballos: Colección de obras (Bogotá, 1996).

13 With combined venues including the Antiguo Colegio de San Ildefonso, Mexico City, the Museo de Arte de Puerto Rico, the University of Toronto Art Centre, and the Los Angeles County Museum of Art, these two exhibitions were truly pan-North American in reach. For catalogues of these exhibitions, see Rishel and
Stratton-Pruitt, eds., The Arts in Latin America; Joseph Rishel and Suzanne L. Stratton-Pruitt, eds., Revelaciones. Las artes en América Latina, 1492-1820 (Mexico City, 2007); Alcalá, ed., Los siglos de oro; and Suzanne L. Stratton-Pruitt, ed., The Virgin, Saints, and Angels: South American Paintings 1600-1825 from the Thoma Collection (Stanford, CA, and Milan, 2006).

14 This is particularly true of Pizano Restrepo and Giraldo Jaramillo. See Alcalá, ed., Siglos de oro, 326. Scholarship linking Gregorio Vásquez to an ideal national character continues to be put forward. As recently as 2008, a critical study identified the artist as both American and Colombian, an "authentic representative of one moment in our national culture." Armando Montoya López and Alba Cecilia Gutiérrez Gómez, Vásquez Ceballos y la crítica de arte en Colombia (Medellín, 2008), 96.

15 Restrepo, Gregorio Vásquez, 322.

16 Santiago Sebastián, "European Models in the Art of the Viceroyalty of New Granada," in Alexandra Kennedy Troya et al., Barroco de la Nueva Granada: Colonial Art from Colombia and Ecuador (New York, 1992), 23-24. See also Alcalá, ed., Siglos de oro, 326.

17 See Alicia Lubowski-Jahn, "Gregorio Vásquez de Arce y Ceballos" in Rishel and Stratton-Pruitt, eds., The Arts in Latin America, 534-35.

18 My thanks to Dr. Lisa Duffy-Zeballos for sharing her notes on the inventories and biographies of Murillo's children. The 1700 inventory includes at least 45 paintings, including bodegones, portraits of "famous captains," and a set of the four seasons.

19 The identification of this print was possible thanks to an extant impression also collected by Daniel Stapleton now in the Denver Art Museum. This print (acquired by Stapleton in South America in the 1910s) was affixed to a wood panel and oil painted. Damage to the paint layer on the lower section of the engraving has revealed the Latin inscription and both artists' in-plate signatures.

20 Serafino Bertolini, La Rosa peruana; overo, Vita della sposa di Christo Suor Rosa di Santa Maria (Rome, 1666). See also Toribio de Mogrovejo et al., Concilia Limana, constitutiones synodales, et alia vtilia monumenta, quibus beatus Toribius Archiepisc. Limanus ecclesias Peruani Imperij mirifice illustrauit (Rome, 1684), which includes works by Thiboust. My thanks to the Project for the Engraved Sources of Spanish Colonial Art for this additional information. See http://colonialart.org/archive/1019a-1019b/saintrose-of-lima (accessed 22 July 2012).

21 The seminal studies of prints and paintings in Colombia were undertaken by Santiago Sebastián, such as "La importancia de los grabados en la cultura neogranadina," in Anuario Colombiano de Historia Social y de la Cultura 3 (1965), 119-53.

22 Sabine MacCormack, "Poetics of Representation in Viceregal Peru: A Walk round the Cloister of San Agustín in Lima," in Pierce, ed., The Arts of South America.

23 Suzanne L. Stratton-Pruitt, The Art of Painting in Colonial Quito (Philadelphia, 2012). 
24 The print with oil paint on paper affixed to wood panel came to the Denver Art Museum with the rest of the Stapleton Foundation donation in 1990.

25 The subject of painted engravings in viceregal Latin America deserves much further study. There is a wealth of examples in the Denver Art Museum alone, which only hints at the prevalence of such objects in the Americas and their important role not only as workshop tools, but also as saleable works of art in their own right.

26 Most of the drawings conform to two standard sizes of approximately $31 \times 22 \mathrm{~cm}$ and $42 \times 31 \mathrm{~cm}$.

27 Denver Art Museum object files and conservation reports. My thanks to Cynthia Lawrence, who generously shared information throughout her treatment of the picture, which took place in the Denver Art Museum conservation lab. Thanks also to paintings conservator James Squires for his valuable insights during the project.

28 Restrepo, Gregorio Vásquez, cat. 465. The Bogotá panel measures $20 \times 25 \mathrm{~cm}$.

29 See Lubowski-Jahn's discussion in Rishel and Stratton-Pruitt, eds., The Arts in Latin America, 451. The monastery was torn down beginning in 1939, and the paintings are now in various private collections and institutions in Colombia.

30 Restrepo, Gregorio Vásquez, 104 and cat. 197.

31 See Alcalá, ed., Los siglos de oro, 329.

32 See Gregorio Vásquez de Arce y Ceballos, 180 and 182.

33 Suzanne L. Stratton-Pruitt, "Painting in South America, Conquest to Independence: An Overview," in The Virgin, Saints, and Angels, p. $85-87$.

34 Restrepo, Gregorio Vásquez, 282. See cats. 36, 68, 88, 182, 249, 342, 255, 293.

35 For a concise list, see Rishel and Stratton-Pruitt, eds., The Arts in Latin America, 535.

36 See Carlos Arbelaez Camacho and F. Gil Tovar, El arte colonial en Colombia (Bogotá, 1968), 160-61.

37 Restrepo, Gregorio Vásquez, 261.

38 This is developed from my discussion of the painting in Pierce, ed., The Arts of South America, 188.

39 See Pamela M. Jones, "Female Saints in Early Modern Italian Chapbooks, ca. 1570-1670: Saint Catherine of Alexandria and Saint Catherine of Siena," in From Rome to Eternity: Catholicism and the Arts in Italy, ca. 1550-1650, ed. Pamela M. Jones and Thomas Worcester, 89-110 (Leiden, Boston, and Cologne, 2002).

40 For an account of the events, see Restrepo, Gregorio Vásquez, $111 \mathrm{ff}$. 